\title{
Thallium-201 SPECT in the Evaluation of Postoperative Tumor Recurrence on the Chest Wall in Lung Cancer
}

Young Hoon Ryu, M.D., Hyung Jung Kim, M.D. ${ }^{1}$, Chul Min Ahn, M.D.', Se Kyu Kim, M.D. ', Hyo Chae Paik, M.D. ${ }^{2}$, Doo Yun Lee, M.D. ${ }^{2}$, Kyung Young Chung, M.D. ${ }^{2}$, Mijin Yune, M.D., Sang June Park, M.D., Sung Wook Moon, M.D., Sang Jin Kim, M.D., Jong Doo Lee, M.D.

Division of Nuclear Medicine, Department of Diagnostic Radiology,

Department of Internal Medicine ${ }^{l}$, Department of Chest Surgery ${ }^{2}$.

Yonsei University College of Medicine, Seoul, Korea*

=국문초록=

폐암 수술 후 흥벽의 종양 재발 검출에 있어 T1-201

폐 SPECT의 유용성

유영휸, 깁형중 ${ }^{1}$, 안철민 ${ }^{1}$, 깁세규 ${ }^{1}$, 백효채 ${ }^{2}$, 이두연 ${ }^{2}$, 정경영 ${ }^{2}$, 윤미진, 박상준, 문성욱, 김상진, 이종두

연세대학교 의과대학 진단방사선과학교실, 내과학교실 ${ }^{1}$ 흥부외과학교실 ${ }^{2}$

Background : 본 연구의 목적은 폐암 수술 후 흥벽의 종양 재발 검출에 있어 Tl-201 폐 SPECT의 유용성을 평가해보고자 하였다.

Methods : 총 28 명의 환자를 대상으로 하였고 이중 14 명의 수술 후 흥벽에의 폐암의 재발이 추적 CT 검 사에서 의심이 되었던 환자와 10 명의 방사선학적, 이학적소견과 홍수의 세포검사모두에서 양성으로 퐌명된 수술 후 흥막 삼출을 보이는 환자군과 4 명의 만성 결핵성 농흥 환자군을 대조군으로 포함하였다. 모든 환 자군에서 $111 \mathrm{MBq}$ 의 Tl-201을 정맥 주사 후 30분과 4시간후에 전신 평면 영상과 홍곽에 대한 SPECT를 시행하였다. 종양의 Tl-201섭취는 2명의 판독자에 의하여 다음의 4단계로 나누어 평가하였다; no uptake:0, similar to contralateral lung:1, higher than contralateral lung but less than heart:2 and similar to heart:3.

This study was supported by a faculty research grant for Yonsei University College of Medicine for 2001 (No. 2001-19)

Address for correspondence :

Young Hoon Ryu M.D.

Division of Nuclear Medicine, Department of Diagnostic Radiology

Yongdong Severance Hospital. Yonsei University College of Medicine,

Kangnamgu Dogokdong 146-92, 135-720, Seoul, Korea.

Tel : 82-2-3497-3518 Fax: 82-2-3462-5472 E-mail : ryuyh@yumc.yonsei.ac.kr 
- Thallium-201 SPECT in the evaluation of postoperative tumor recurrence on the chest wall in lung cancer -

Results : 수술 후 흥벽에의 폐암의 재발이 추적 CT 검사에서 의심이 되었던 환자 14 명 중 13 명에서 Grade 3또는 2의 강하게 증가된 T1-201의 섭취를 보였다. 그리고 14명중 2명에서는 CT에서 관찰되지 않았 던 다른 부위의 종양 재발을 확인 할 수 있었다. 반면에, 양성 수술 후 흠막 삼출군에서는 섭취가 없거나 (8/10) 또는 허탈된 폐에 미미한 (grade 1) Tl-201의 섭취만을 보였다. 만성 결핵성 농흥군에서는 비교적 균일하게 경계를 보이는 미약한 정도의 (grade 1 or 2) Tl-201의 섭취를 보였다.

Conclusion : T1-201 폐 SPECT는 폐암 수술 후 홍벽의 종양 재발 검출에 있어 CT에서 제공하는 형태학 적인 정보이외의 종양 재발에 관한 기능적 정보를 더 제공하며, PET이 없는 기관에서 사용 가능한 유용한 방법이 될 수 있을 것으로 생각된다. (Tuberculosis and Respiratory Diseases 2002, 53:542-549)

Key words: Lung, Neoplasm, Recurrence, Thallium-201, SPECT.

Difficulties are encountered in the detection of tumor recurrence on chest wall in patients treated for lung cancer. Computed tomography (CT) is currently the imaging method of choice in following up of patients who treated lung cancer. However, current imaging studies including CT provide valuable information but it is usually no specific enough to aid in the clinical management. Therefore, many patients undergo invasive procedures to determine the tumor recurrence and help guide patient care after treatment for lung cancer.

Several PET studies have confirmed that FDG-PET is reasonably good predictors of residual tumor or tumor recurrence ${ }^{1-3}$. Patz et al showed a sensitivity of $97 \%$ and specificity of $100 \%$ for FDG-PET in distinguishing tumor recurrence from residual fibrosis in 38 patients treated for bronchogenic cancer ${ }^{3}$. However, FDG-PET remains a relatively expensive and complicated procedure and is available at only a very limited number of sites.

Several studies have been performed to investigate the use of $\mathrm{Tl}-201$ imaging in the detection of malignancy ${ }^{4-8}$. The potential clinical utility of T1-201 is probably related to its mechanism of localization, which passes intracellularly to viable tumor, although mechanism of T1-201 uptake are not clearly defined ${ }^{8}$. Moreover, attempts had been made to distinguish tumor recurrence and radiation fibrosis especially in brain tumors ${ }^{9-11}$.

In this work, we report the result of the studies designed to evaluate the tumor recurrence of chest wall in patients who underwent treatment for bronchogenic carcinoma and were suspected for tumor recurrence on chest wall or were found to have residual or newly developed abnormalities on chest radiographs or CT scan. This study focused on the ability of T1-201 SPECT imaging for the detection of the postoperative tumor recurrence on chest wall and for differentiation malignant from benign pleural effusion.

\section{PATIENTS AND METHODS}

28 patients (21 male, 7 female: age 38-69 years) including 10 with suspected recurrence of tumor in the chest wall on postoperative chest CT scan, 
Table 1. Postoperative chest CT findings of each groups

\begin{tabular}{cccc}
\hline \hline CT findings & $\begin{array}{l}\text { Suspected } \\
\text { tumor recurrence }\end{array}$ & $\begin{array}{l}\text { Benign postoperative } \\
\text { effusion }\end{array}$ & $\begin{array}{l}\text { Chronic tuberculous } \\
\text { empyema }\end{array}$ \\
\hline Operation & 11 & 9 & 0 \\
Pneumonectomy & 3 & 1 & 0 \\
Lobectomy & & & 2 \\
Pleural thickening & 14 & 4 & 2 \\
Irregular & 0 & 6 & \\
Smooth & 14 & & \\
\hline
\end{tabular}

10 with postoperative pleural effusion which proved benign on radiologic, cytologic and laboratory findings, and 4 with chronic tuberculous empyema as control group were included. Patients who were suspected tumor recurrence on chest wall or had benign postoperative pleural effusion had performed pneumonectomy or lobectomy for lung cancer 9 to 25 months prior to Tl-201 lung SPECT. Tl-201 SPECT and chest CT scan were performed within a week. Suspicion of tumor recurrence was based on a deteriorating clinical course, a suspicious change in CT examination, or both. Informed consent was given by all patients. Chest $\mathrm{CT}$ scans were obtained with $\mathrm{GE}$ 9800 scanner (General Electrics, Milwaukee, WI, USA). Continuous $1^{-} \mathrm{cm}$-thickness sections were obtained at $1-\mathrm{cm}$ interval from the lung apices to the adrenal glands. Contrast material (Optiray 320, Mallinkrodt Medical Inc., Quebec, Canada) was intravenously administered (total amount, 100 ml). A SPECT study of the lung was obtained 30 minutes and 4 hours after intravenous injection of $111 \mathrm{MBq}$ (3mCi) of $\mathrm{Tl}-201$ on a dual-headed gamma camera (ADAC, Milpitas, CA) equipped with a high-resolution, low-energy parallel hole collimator. Sixty-four projections with an acquisition time of $40 \mathrm{sec} /$ view were acquired in $64 \mathrm{X}$
64 matrices with a 5.6-degree of angular increment. The images were reconstructed with a filtered back projection method using a Butterworth filter (cut-off frequency of 0.35 cycle/cm at order no.5). Attenuation correction was not performed. Thallium activity of the tumor was visually graded by two nuclear medicine physicians and scored as follows: no uptake:0, intensity similar to that of the contralateral lung:1, higher than that of the contralateral lung but less than that of heart:2 and similar to that of the heart:3. In two patients, follow-up T1-201 SPECT was performed after radiation therapy of the recurrent tumor mass on the chest wall to evaluate treatment response.

\section{RESULTS}

Clinical data and radiological findings including postoperative chest $\mathrm{CT}$ scan of all patients are summarized in Table 1.

Initial agreement was complete between two readers in the interpretation of each of the $\mathrm{Tl}-201$ SPECT scan except one patient, which was resolved by consensus. In early SPECT images taken 30 minutes after intravenous injection of T1-201, markedly increased T1-201 uptake was 
Table 2. T1-201 SPECT findings of each groups

\begin{tabular}{lccc}
\hline $\begin{array}{l}\text { T1-201 SPECT } \\
\text { findings }\end{array}$ & $\begin{array}{c}\text { Suspected } \\
\text { tumor recurrence }\end{array}$ & $\begin{array}{c}\text { Benign postoperative } \\
\text { effusion }\end{array}$ & $\begin{array}{c}\text { Chronic tuberculous } \\
\text { empyema }\end{array}$ \\
\hline $\begin{array}{l}30 \text { minutes SPECT } \\
\text { Grade } 3\end{array}$ & 11 & 0 & 0 \\
2 & 2 & 0 & 1 \\
1 & 1 & 4 & 3 \\
0 & 0 & 6 & 0 \\
4 hours SPECT & 10 & & 0 \\
Grade 3 & 3 & 0 & 0 \\
2 & 1 & 0 & 4 \\
1 & 0 & 4 & 0 \\
0 & & 6 & 0 \\
Pattern of uptakes & 14 & & 4 \\
Focal, Irregular & 0 & 2 & \\
Diffuse, Smooth & & & \\
\hline
\end{tabular}

noted in all patients with suspected recurrence of tumor in the chest wall, grade 3 in eleven patients and grade 2 in two patients(Table 2, Fig. 1A, B). In two patients who had received radiation therapy for the recurrent tumor mass on the chest wall after initial Tl-201 SPECT, follow-up SPECT 3-4 weeks after cessation of radiation therapy revealed disappearance of increased thallium uptake (Fig. 1C). In other two patients, Tl-201 SPECT depicted additional recurrent tumor mass lesions that were barely perceptible on chest CT scan (Fig. 1B, D). No significant difference was noted in uptake of T1-201 by the recurrent tumor between early and delayed SPECT. Of those 14 patients in whom recurrence of the tumor on chest wall was suspected, 8 patients performed biopsy and confirmed the recurrence of the tumor. Whereas no (8 patients) or grade 1 (2 patients) uptake along the collapsed lung were seen in patients with postoperative benign pleural effusion (Table 2, Fig. 2). Patients with chronic tuberculous empyema showed increased $\mathrm{Tl}-201$ uptake as well, but in lesser degree (grade 1 or 2), when compared to recurrent tumor uptake, and depicted relatively smoothly marginated increased uptake along the chest wall in all four patients.

\section{DISCUSSION}

Response to therapy is continually reassessed with imaging studies such as chest radiography, CT and MRI. These modalities provides important anatomic and morphologic information but cannot always help distinguish residual or recurrent turnors from benign post-treatment changes ${ }^{12,13}$. Some patients may undergo a biopsy to determine tumor viability, although invasive procedures, which include transthoracic needle biopsy, pleural biopsy and open lung biopsy, have associated risks. These procedures, however, do not always provide a definite answer, particularly when residual abnormalities are seen on radiographs, because sampling errors may occur. A new, 


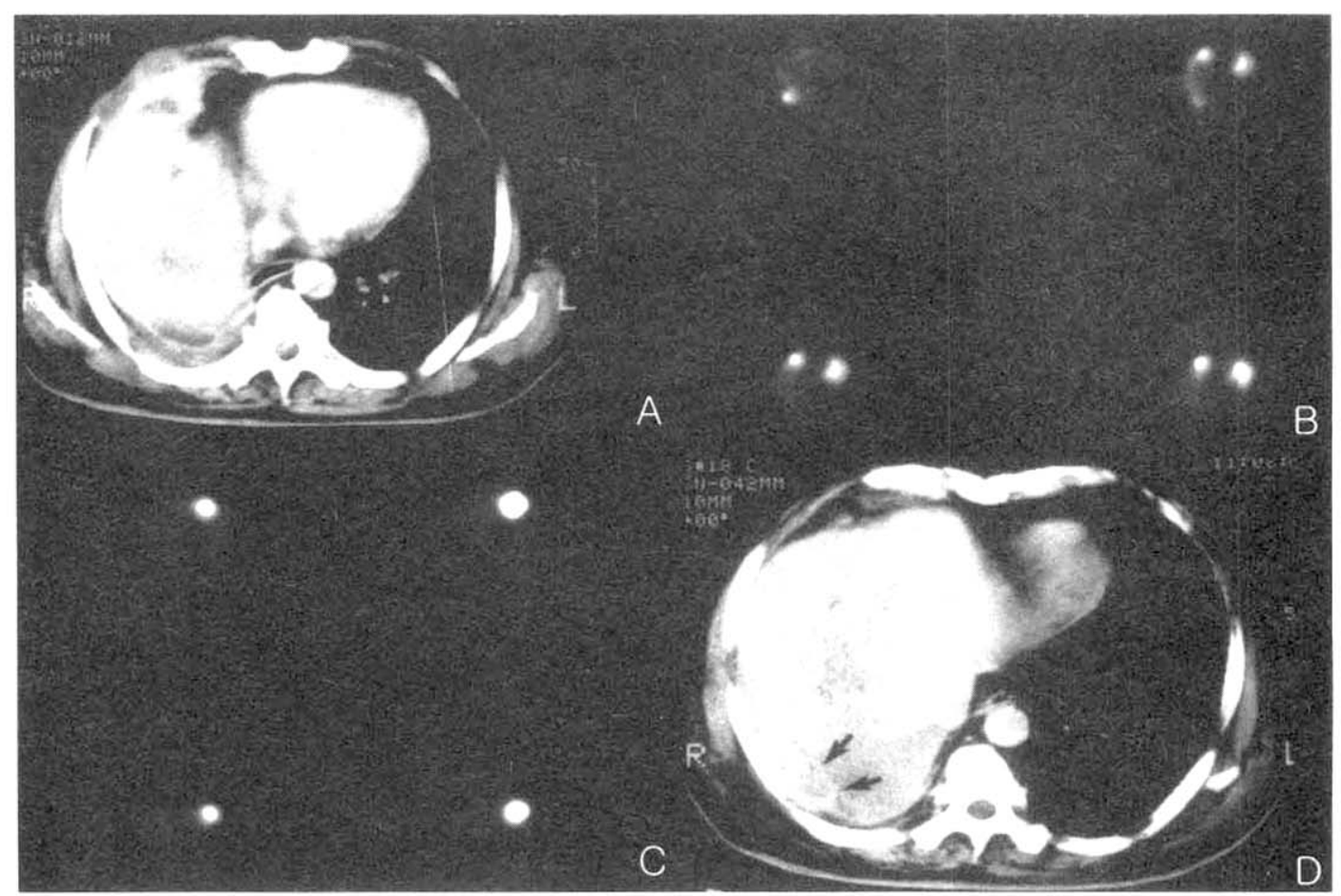

Fig. 1. 60-year old male patient who had received right pneumonectomy 1 year ago for known squamous cell carcinoma. Postoperative chest CT scan revealed irregular marginated chest wall mass with enhancement on anterior and posterior chest wall (A). 4-hour delayed SPECT images showed grade 3 increased T1-201 uptakes on anterior and posterior chest wall which were corresponded to chest CT scan abnormalities (B). However, additional focus of grade 3 increased uptake was depicted on lower posterior thorax and meticulous retrospective review of chest CT scan showed another recurrent tumor mass lesion (D). The patient had received radiation therapy for the recurrent tumor mass on the chest wall after initial T1-201 SPECT, follow-up SPECT 3-4 weeks after cessation of radiation therapy revealed complete disappearance of previously increased uptakes (C).

noninvasive technique with the ability to help assess treatment efficacy would be invaluable.

Tl-201 has been used to evaluate the tumor viability since it passes intracelluarly to viable tumor. The mechanism of thallium uptake in tumor cells, although details have not been entirely elucidated. Several studies have been performed to investigate the use of Tl-201 imaging in the detection of malignancy and
Tl-201 chloride has been described as a positive indicator for lung neoplasms irrespective of histology. Differentiation of tumor recurrence from benign postoperative changes is important in the management of patients who treated lung cancer. Attempts have been made to distinguish tumor recurrence and post-treatment changes using thallium-201 SPECT in brain tumors and found useful in the evaluation of treatment response $e^{9-11}$. 
- Thallium-201 SPECT in the evaluation of postoperative tumor recurrence on the chest wall in lung cancer -
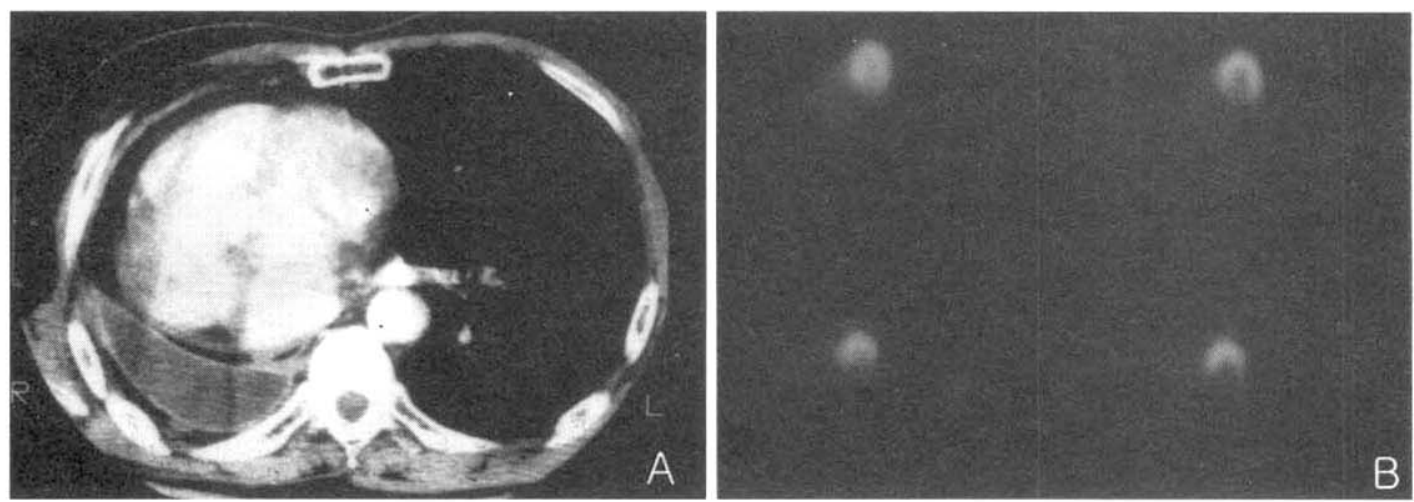

Fig. 2. 57-year old male patient who had received right pneumonectomy 2 year ago for known squamous cell carcinoma. Postoperative chest CT scan revealed small amount pleural effusion without evidence of chest wall mass or abnormal focal thickening or enhancement of pleura or chest wall (A). 4-hour delayed SPECT images showed no abnormal increased T1-201 uptakes on chest wall (B).

Several PET studies have confirmed that FDGPET is reasonably good predictors of residual tumor or tumor recurrence ${ }^{13,14,15}$. However, FDGPET remains a relatively expensive and compli cated procedure and is available at only a very limited number of sites. The technology needed to perform SPECT with Tl-201, on the other hand, is widely available and cost-efficient. Moreover, in a study of Kahn et al about recurrent brain tumor, they demonstrated no statistically significant difference in sensitivity or specificity between the Tl-201 SPECT and FDG-PET ${ }^{11}$.

On the basis of these considerations, we performed Tl-201 lung SPECT for the evaluation of tumor recurrence and benign postoperative changes. The results of our study showed that recurrent tumor on chest wall revealed signifi cantly increased thallium uptake, whereas benign postoperative pleural effusion or tuberculous empyema revealed no or faint smoothly marginated uptake of thallium.
Although other entities can cause an increase of Tl-201 uptake $^{16}$, our results suggest that Tl-201 lung SPECT can play an important role in guiding patient care after treatment for lung cancer and, if necessary, can direct biopsy for pathologic confirmation. Tl-201 SPECT more accurately represents post-therapy viable tumor burdens than do other imaging modalities such as CT. Thus, at this time, we consider abnormal findings on postoperative Tl-201 SPECT after operation to be indicative of tumor recurrence until proven otherwise. Patients with residual abnormalities on radiographs and normal findings on Tl-201 SPECT scans will almost certainly be considered as absence of tumor recurrence.

In conclusion, Tl-201 lung SPECT seems to be useful to detect postoperative tumor recurrence on chest wall and to differentiate malignant from benign pleural effusion and may provide additional information to the morphologic data obtained by CT. 


\section{Summary}

Purpose : The purpose of our study was to assess the usefulness of the T1-201 SPECT for the detection of the postoperative tumor recurrence on chest wall.

Methods : 28 patients including 14 with suspected recurrence of tumor in the chest wall on postoperative chest CT scan, 10 with postoperative pleural effusion which proved benign on radiologic, cytologic and laboratory findings, and 4 with chronic tuberculous empyema as control group were included. All patients underwent SPECT 30 minutes and 4 hours after intravenous injection of $111 \mathrm{MBq}$ of Tl-201. Tumor uptake was visually graded by two interpreters and scored as follows : no uptake:0, similar to contralateral lung:1, higher than contralateral lung but less than heart:2 and similar to heart:3.

Results : Markedly increased (grade 3 or 2) T1-201 uptake was noted in patients with suspected recurrence of tumor in the chest wall $(13 / 14)$ whereas no $(8 / 10)$ or minimal (2/10) uptake along the collapsed lung in patients with postoperative benign pleural effusion. In two patients, Tl-201 SPECT revealed additional recurrent tumor mass lesions that were barely perceptible on chest CT scan. Patients with chronic tuberculous empyema showed relatively smoothly marginated increased uptake along the chest wall (4/4), but lesser in degree (grade 1 or 2 ), when compared to recurrent tumor uptake.

Conclusion : T1-201 lung SPECT seems to be useful to detect postoperative tumor recurrence on chest wall and to differentiate malignant from benign pleural effusion and may provide additional information to the morphologic data obtained by CT.

\section{REFERENCES}

1. Ichiya Y, Kuwabara Y, Sasaki M, Yoshida $\mathrm{T}$, Omagari J, Akashi $\mathrm{Y}$, et al. A clinical evaluation of FDG-PET to assess the response in radiation therapy for bronchogenic carcinoma. Ann Nucl Med 1996:10:193-200

2. Erasmus JJ, McAdams HP, Patz EF. Nonsmall cell lung cancer: FDG-PET imaging. J Thorac Imaging 1999;14:247-56

3. Patz EF Jr, Lowe VJ, Hoffman JM, Paine SS, Harris LK, Goodman PC. Persistent or recurrent bronchogenic carcinoma: detection with PET and 2-[F-18]-2-deoxy-D-glucose. Radiology 1994;191:379-82

4. Tonami N, Shuke N, Yokoyama K, Seki H, Takayama T, Kinuya S, et al. Thallium-201 single photon emission computed tomography in the evaluation of suspected lung cancer. J Nucl Med 1989;30:997-1004

5. Lee JD, Lee BH, Kim SK, Chung KY, Shin DH, Park CY. Increased thallium-201 uptake in collapsed lung: a pitfall in scintigraphic evaluation of central bronchogenic carcinoma. J Nucl Med 1994;35:1125-8

6. Suga K, Kume N, Orihashi N, Nishigauchi $\mathrm{K}$, Uchisako $\mathrm{H}$, Matsumoto $\mathrm{T}$, et al. Difference in ${ }^{201} \mathrm{Tl}$ accumulation on single photon emission computed tomography in benign and malignant thoracic lesions. Nucl Med Commun 1993;14:1071-8

7. Chin BB, Zukerberg BW, Buchpiguel C, Alavi A. Thallium-201 uptake in lung 
- Thallium-201 SPECT in the evaluation of postoperative tumor recurnence on the chest wall in lung cancer -

cancer. J Nucl Med 1995;36:1514-9

8. Yamamoto Y, Nishiyama Y, Fukunaga K, Satoh K, Ohkawa M. TI-201 chloride and Tc-99m MIBI accumulation in lung adenocarcinoma in patients with and without distant metastases. Clin Nucl Med 2001;26: 751-6

9. Vertosick FT Jr, Selker RG, Grossman SJ, Joyce JM. Correlation of thallium-201 single photon emission tomography and survival after treatment failure in patients with glioblastoma multiforme. Neurosurgery 1994;34: 396-401

10. Elgazzar AH, Fernandez-Ulloa M, Silberstein EB. ${ }^{201} \mathrm{Tl}$ as a tumour-localizing agent : current status and future considerations. Nucl Med Comm 1993;14:96-103

11. Kahn D, Follet KA, Bushnell DA, et al. Diagnosis of recurrent brain tumor : value of ${ }^{201} \mathrm{Tl}$ SPECT vs ${ }^{18} \mathrm{~F}$-fluorodeoxyglucose PET. Am J Roentgenol 1994;163:1459-65
12. Pennes DR, Glazer GM, Wimbish KJ, Gross $\mathrm{BH}$, Long RW, Orringer MB. Chest wall invasion by lung cancer: limitations of $\mathrm{CT}$ evaluation. Am J Roentgenol 1985;144:507-11

13. Vansteenkiske JF, Stroobants SG. Kuriyama $\mathrm{K}$, Tateishi R, Kumatani $\mathrm{T}$, et al. Pleural invasion by peripheral bronchogenic carcinoma: assessment with three-dimensional helical CT. Radiology 1994;191:365-9

14. Erasmus JJ, Patz EF, Positron emission tomography imaging in the thorax. Clin Chest Med 1999;20:715-24

15. Kim EE, Chung SK, Haynie TP, et al. Differentiation of residual or recurrent tumors from post-treatment changes with $\mathrm{F}-18$ FDG-PET. Radiographics 1992;12:269-79

16. Abdel-Dayem H, Bag R, Macapinlac H, Elgazzar AH, Habbab N, Pescatore F, et al. Diffuse Tl-201 uptake in the lungs: etiologic classification and pattern recognition. Clin Nucl Med 1995;20:164-72 